\title{
REGIONAL RESURGENCE OF WOOL
}

\author{
ANDRA CAMELIA CLITAN \\ University of Sharjah, UAE
}

\begin{abstract}
To sustain authenticity, a holistic approach to preserving arts, crafts, and the fabric of the place must be perpetuated integrally. This research analyzes wool as a sustainable engine for local communities in Transylvania, Romania, and a tool for its artists and creatives to interpret it through different techniques and mediums to contribute to its continued preservation and perpetuation through generations. In Transylvania, the art and craft of processing wool continue to be part of the region's heritage. In order to sustain this practice, both as the basis for the economy and the people's heritage, it is necessary to seek alternatives to engage the older craftsmen while attracting the younger generation. There must be a continuum of practice to transfer knowledge and know-how. The paper is based on a recently completed case study entitled "A Wool Journey: From Fashion Design to Art Installation". The project, which started in 2019, was financed by the Romanian Ministry of Culture and had two main objectives: to create a collection using wool as a foundation fabric for technical and material experimentation, making use of ancestral crafts and symbols from different parts of Maramureș, Transylvania, and to document the entire process of wool processing and manufacturing. The final result was revealed in the form of an art installation that highlighted this journey a journey that reinforced the importance of place. This journey started in Săpânța, home of the Merry Cemetery, a UNESCO heritage site, where the physical fabric of the place lends itself to sustaining the local crafts and craftsman. Therefore wool, perceived in Maramureș as having the same value as gold, soil, wood, and water, is attributed to new valences and focus, becoming a tool for the local community to perpetuate its heritage, necessary to its continuance.
\end{abstract}

Keywords: wool, heritage, Transylvania, Maramureș, crafts, craftsman, craftsmanship, cultural site, habitat.

\section{INTRODUCTION}

Living in an age where traditions are starting to fade away and younger generations turn more and more to new opportunities, in Romania, and precisely in Transylvania, entire communities are striving to keep true to their ancestral crafts and customs, by perpetuating them not only locally, but globally as well. Although, in these areas, traditions and customs are part of everyday life, well preserved by generations, technology hasn't totally replaced the ancestral practices, boasting a civilization that today proudly displays a bucolic countryside carved in wood. Some people would call it a "cultural miracle", passed through from generation to generation due to the immense love and dedication people have to their crafts.

Ancestral practices have been passed from generation to generation, such examples include beading, weaving, pottery making, wood carving, embroidery, knitting or crochet, wool processing being of tremendous importance, especially when discussing the region of Transylvania, with a wide mountain landscape and lower temperatures than the South and East of the country.

Romanian symbolism associates wool with prosperity, wealth, and fecundity; wool is the symbol of sun and gold, it is more likely about spirituality than materiality: wool signifies purity and truth. In addition, wool was one of the first fibers available for humans, serving as a primary necessity for protecting the body.

As Szabó mentioned in his book "Wool Story", for the Romanian villagers from Maramureș county (in Transylvania), wool processing was indeed more important than 
going to war, because "while war was killing people, wool was saving them" [1]. Thus, this material has ancestral ties with human evolution, having significant importance globally, mostly in areas with wider mountain landscapes and mild climate.

Sheep and sheep flocks have always been an integral part of the Transylvanian landscape, dispersed around its fields, in a unique interconnection. The land in this area has never failed to loyally and tacitly give a supporting ground, by simply existing, over 3 million hectares covered in rich grass, good for grazing.

Having all the means for successful development of the wool sector in the rural area, it is here where this precious material found its utility, local craftsman or small manufacturers taking it over to generations to come, contributing to its preservation.

Documenting the processes encountered in wool processing and wool crafts, it is of major importance not only for history and social fields, but a continuous source of information, social and economic purposes, and future sustainable development. Moreover, it is an area that could very well represent a strong foundation for economic and touristic development.

"Beyond the story, it is a reality that wool has the same value as gold, soil, wood, and water. Even 29 varieties of seeds, carried by the tail of a ram from one side of the world to another, as biologists say, could save a lot of species of plants and grow biodiversity. So, wool can protect plants and people" [1].

The aim of this research is to highlight the interconnectivity between the craftsman, the craft, and the environment towards a sustainable presence and operation. Cultural heritage, including cultural heritage sites, as well as folklore and archaeological sites and "lived in" museums represent an important part of the whole, each piece completes the other. In order to preserve this interdependency, which stands as the starting point, the sanctuary for local craftsmen and communities, it has to be integrated within the contemporary comfort, as well as discussed and presented to the world. This will not only provide awareness, but also exposure, attracting more lucrative opportunities and sustained development.

\section{METHODOLOGY}

This research takes a qualitative approach, to investigate non-numeric data, concerning ontological points of cultural heritage/community/local habitat in Maramureș, Romania. It investigates the role of crafts as a sustainable engine for local communities and suggests measures to be taken considering their preservation for future generations. This research aims to present the reality of the place through verified hypotheses, as such this has been achieved in two parts: an archival research of the historical material presented and a case study of the local communities in Maramures, Romania. The case study had a documentation part (starting from the origins, including sites visits, working and interviewing local craftsmen). The outcome of the documentation was then integrated into contemporary designs and applications. The final results were presented in the form of an exhibition. Combining both the argumentation and a creative, practical solution was considered as the best way to achieve the desired outcome.

\section{WOOL IN TRANSYLVANIA}

In Transylvania, the mild climate is favorable for the more native type of sheep, "Țurcana" and "Tigaie", which are proven to be less pretentious, resistant, and adaptable to the environment, says Florica Zaharia in her book, Traditional Textiles from Transylvania [2]. Both kinds of sheep are local races, with moderate wool production capacity, being raised for the wool, meat, and skin. The "Turcana" type of sheep produces a thick, straight, and long fiber that is generally used for weaving the items serving as interior decoration or 
heavy blankets. A good sheep could produce up to 3 kilograms of wool during a year, producing up to half the size of inferior quality ones. The color of the wool commonly encountered is white, but occasionally black, brown, or grey can also be found.

Until the mid-20th century, each family had between 5 to 20 sheep, a number that was meant to cover the necessities exclusively for clothing and domestic textiles/objects and meat, the lamb making the traditions for the Easter holiday in Romania. Wool processing was and continues to be a yearly process within a very precise and ongoing circle. Besides each household's wool reserve, there were herds of sheep maintained for wool processing and sale. The complexity of the technological process of wool processing, common in the entire region of Transylvania, did not change over the years and continues in the present, keeping almost the same format.

At the beginning of the 20th century, due to the origination of teasel and spun tools, these operations became partially automatic. The sequence of stages took place annually, in a rhythm that follows the seasons, starting in spring with the wool shearing (Fig. 1) and continuing with its cleaning/washing/scouring in summer (when the temperatures reach 22$25^{\circ}$ Celsius and humidity around $10-15 \%$, as seen in Fig. 2 , then carding, sorting, combing and spinning in autumn, followed by weaving and knitting in late autumn and during the cold winters. At present, the processing is done according to the needs of each individual or household in a very sustainable manner.

\section{WOOL DYEING}

Up to around the beginning of the 20th century, traditional textiles dyed exclusively using natural resources, as such, black, brown, and grey, were primarily obtained from "colored" animals and strong primer colors (like red, yellow, or blue) from wild plants growing around the house/yard, or fields, available in the same geographical area. The immense natural richness of Transylvania made these practices easier, giving variety as well as a strong foundation for wool-based crafts/or craftsmanship. Dyeing is a craft, like all other crafts in the region, that has been transmitted from generation to generation, where
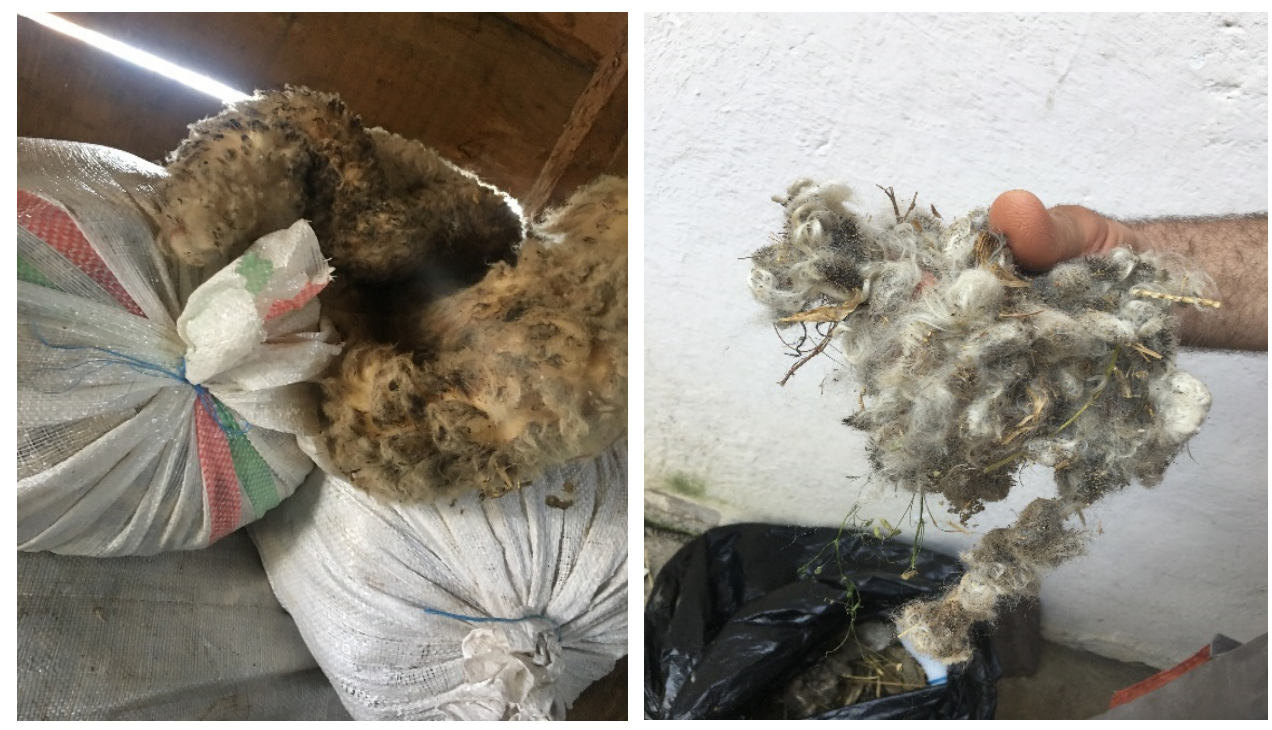

Figure 1: Unwashed wool. (Source: Author.) 

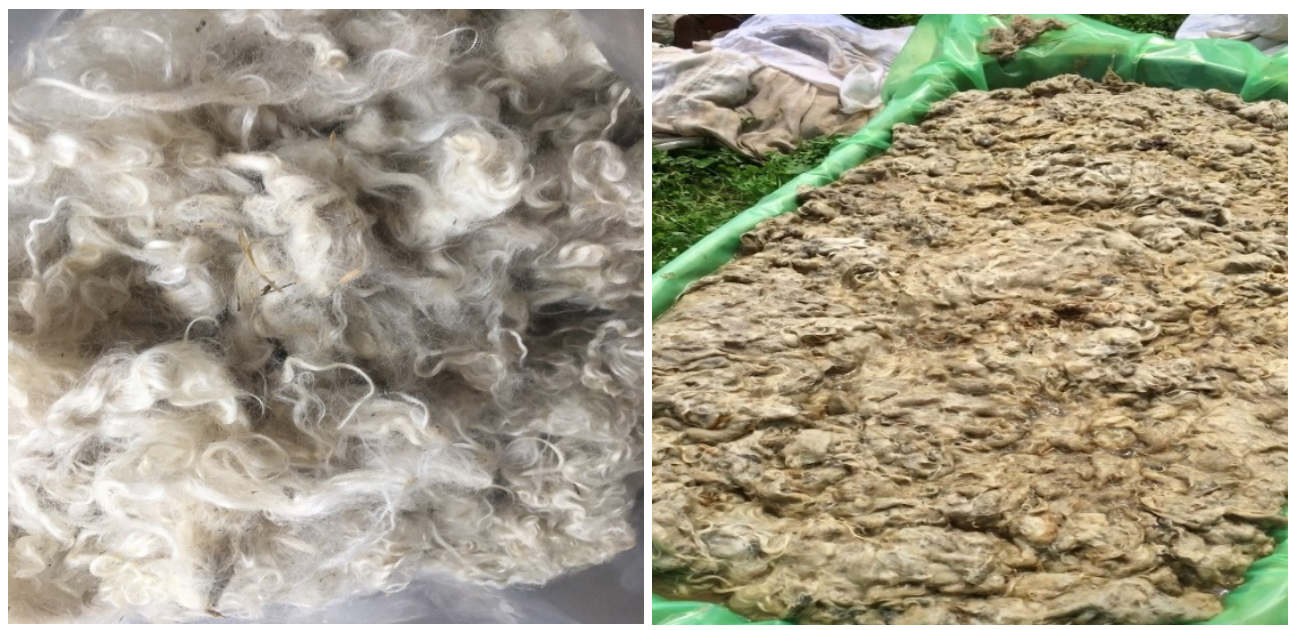

Figure 2: Washed and washing wool. (Source: Author.)

mastering them requires extensive and rigorous practice that the local craftsman understood. Nothing was left to chance; rather, every step is researched, practiced, and assimilated in order to be passed on.

Traditional textiles are perceived as true examples of artistic creation and mastership, as their aesthetic appearance can change with the manufacturing and finishes techniques chosen to be used. However, the techniques used for the manufacturing and finishes, as well as the patterns, colors, or textures, are all coming together in a true artistic expression, following precise guidelines that have been in place for generations.

\section{WOOL CRAFTS}

Preserving ancestral crafts is not only the fundament of a nation but the starting point for contemporary design. One's creative path cannot stand for authenticity and longevity forgetting its culture's fundament. The craftsmen from Maramureș taught us all the secrets learned from their parents and grandparents. What comes from their hands is pure magic, a real work of art created with love, passion and patience. At the same time, it is based on precise knowledge, know-how and experience.

Maramuress, Transylvania is the dream place where amongst an extremely rich landscape, with amazing nature and natural resources, rural areas are fortunate to host talented craftsmen that kept traditions alive through generations. It is true that with years and new industrial developments, keeping ancestral practices alive has proven to be more and increasingly challenging. Nevertheless, one can still encounter practices like spinning (Figs 3-5), weaving, felting, knitting, crochet practice, embroidery, pottery, wool processing, and so on, entirely practiced in the craftsman's household (either inside the house, courtyard, or built-in workshops). And every crafted item that comes out of these magic hands has a particular energy that cannot be repeated twice identically; it is the energy associated to the unschooled rhythm, the one linked to the nature; nothing is imposed but left for self-expression. Creating a suitable habitat, that follows the natural rhythm of nature and community, is it part of a traditional maker lifestyle, one cannot create without the foundation and support of the environment. One such creator cannot subsist outside the personal habitat, part of a wider circle. 


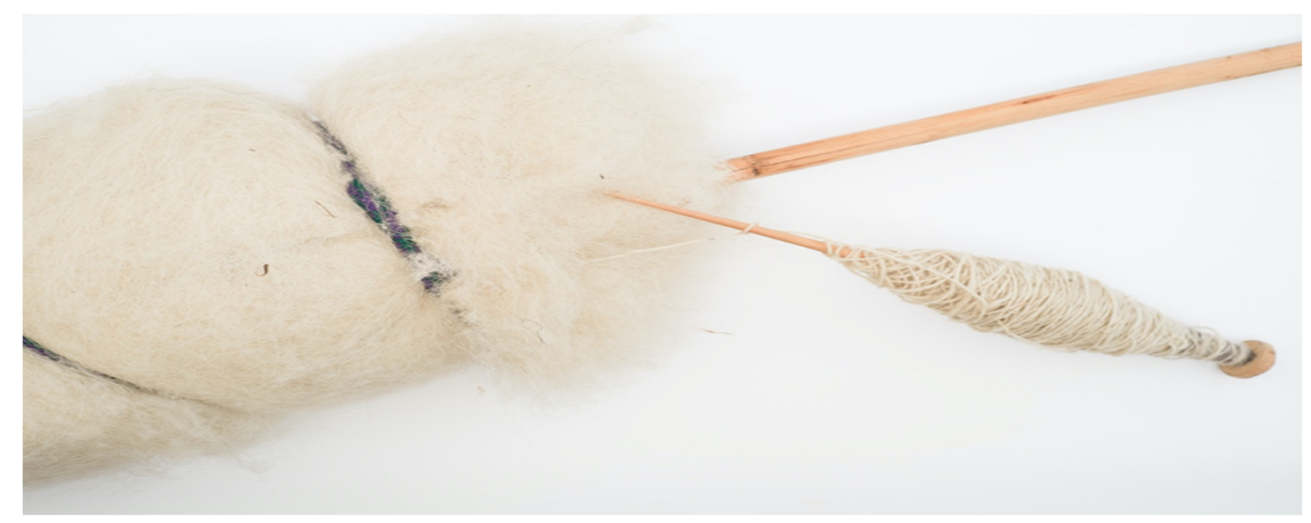

Figure 3: Wool spindle. (Source: Iulian Nan.)

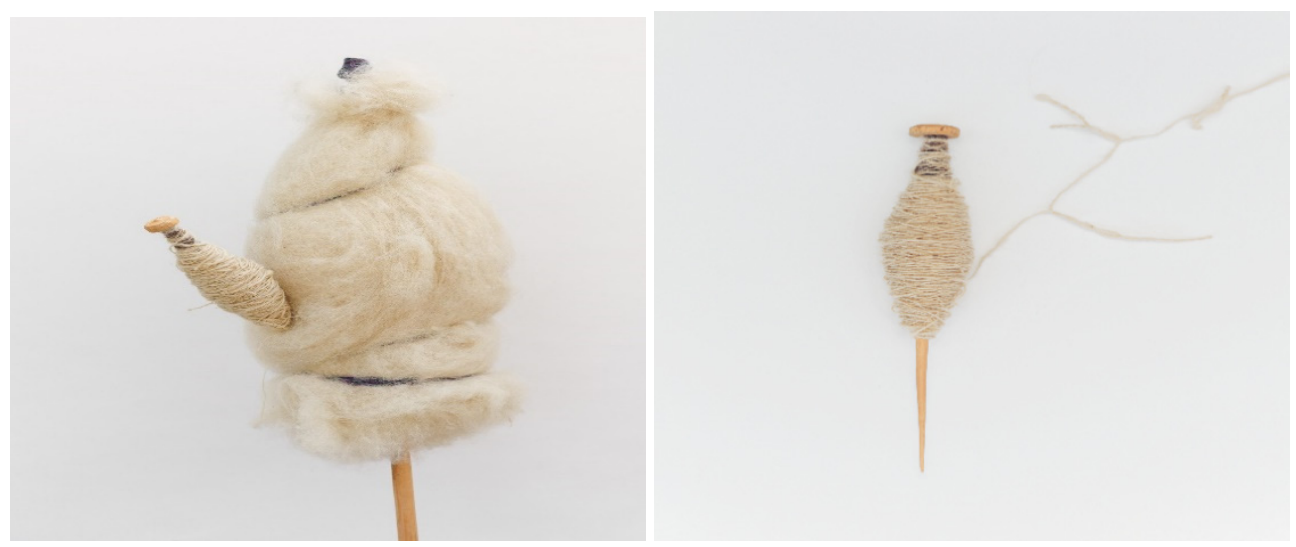

Figure 4: Wool spindle. (Photo Credit: Iulian Nan.)

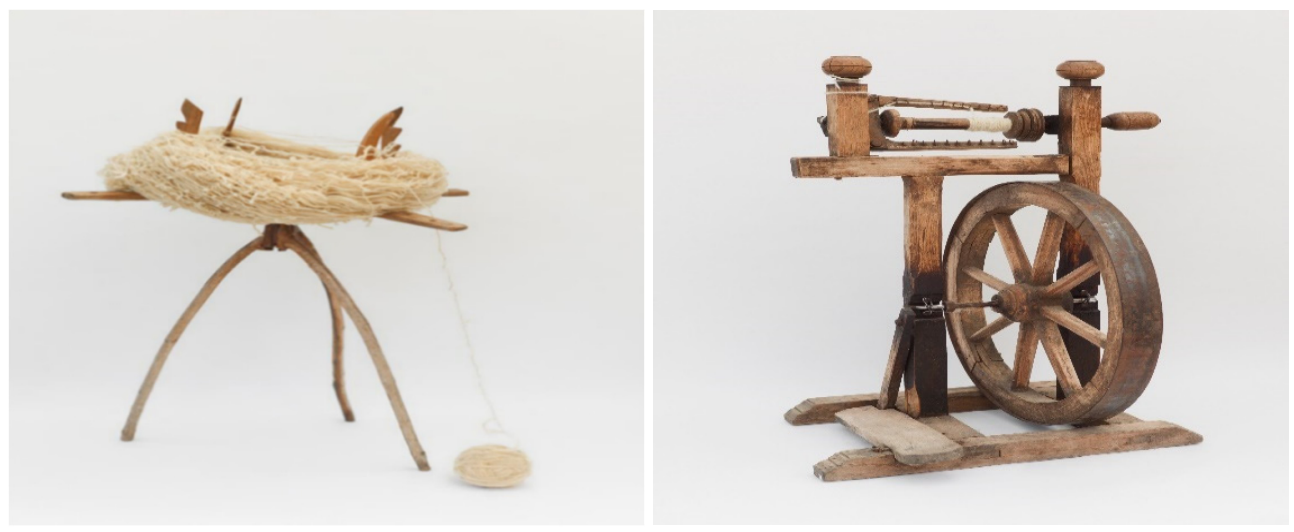

Figure 5: Wool processing. (Source: Iulian Nan.) 


\section{LOCAL HERITAGE IN CONTINUUM}

Working with craftsman from Maramureș, Transylvania, has been the motivation behind this project over a decade ago. This journey of authenticity, connecting to our ancestors and rediscover their crafts, in order to acknowledge, understand and pass on to future generations, is work in progress. Born and raised in this region, I became familiar with the local crafts at an early age and turned it into a main interest to contribute to preserving and conveying to the world, the unicity traditional culture has to offer.

Maramureș is divided into "four countries", the Historic, Lăpuş, Chioar and Codru, each having different characteristics of its traditional costumes, habits, nevertheless, mostly keeping the same practices and techniques, as well as fabrics. Differences are noticeable in the patterns, colours, items layout, and so on. Traditional costumes reflect codes, shapes, and meanings that are common to an entire social group, expressing the communitarian function of traditional art [3]. Consequently, each community has its own particularities when discussing fabric attributes (materiality, patterns, design), which are different from community to community, even if common regional features can be found, says Ana Iuga in her paper, "Contemporary Traditional Clothing in Maramureș" [5].

As such, clothes help people differentiate from each other amongst different communities, and people took extreme pride over this (such examples can be seen in Fig. 6). The difference, though, is not only visible when reflecting on traditional costumes, but also customs, architecture, food, and others, contributing to a diversity well embraced since ancestral times.
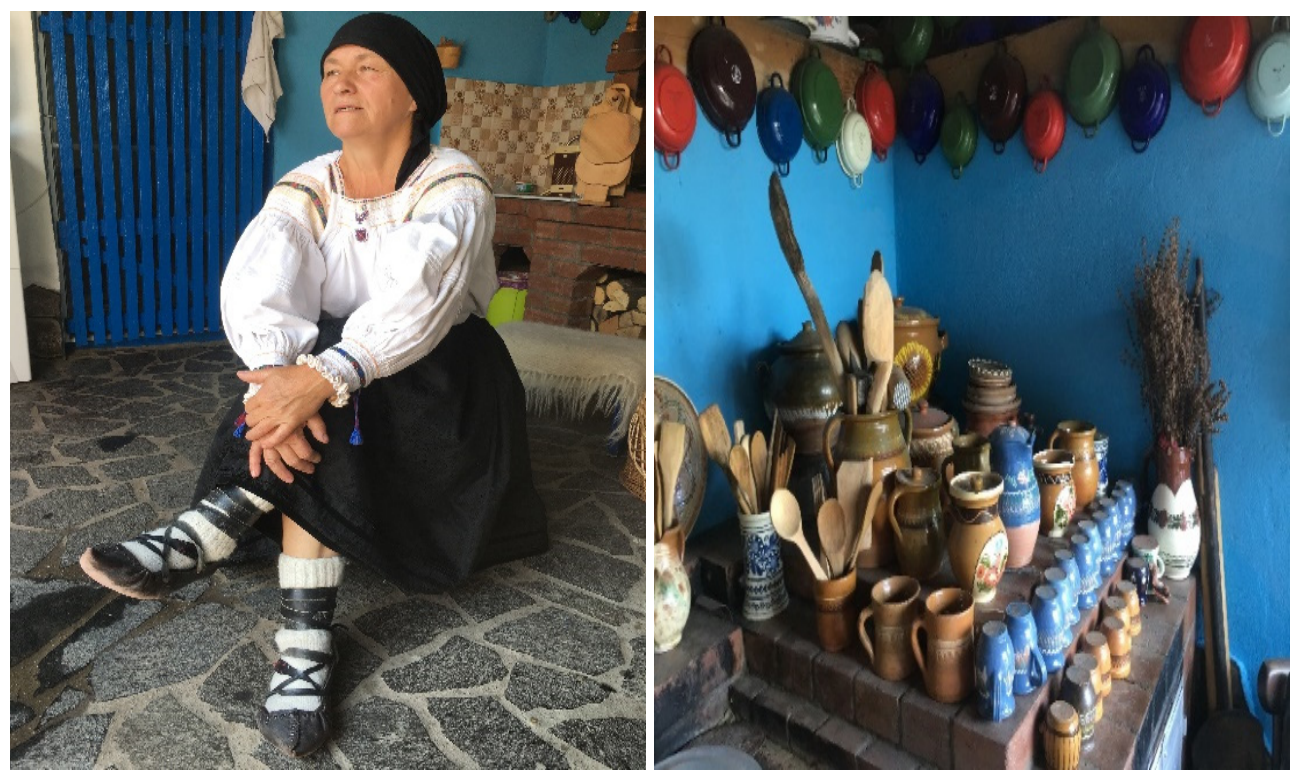

Figure 6: Traditional peasant costume from historic maramureș and traditional objects. (Source: Author.)

\section{A WOOL JOURNEY - A CASE STUDY}

"A Wool Journey: from Fashion Design to Art Installation" represents a project [6] initiated in 2019, in order to continue my commitment to promoting Romanian cultural heritage and 
its authentic design. The goal of the project was to connect with public interested in the meeting of traditions, fashion and textile design, and the cultural heritage of our times.

Having started this journey a long time ago, the desire to connect to my ancestors came as an inherent fact while growing up in the region. I, therefore, believe that preserving ancestral crafts is not only the fundament of a nation but the starting point for contemporary design. One's creative path cannot stand for authenticity and longevity while forgetting the fundament of its culture.

This project presents the result of a conscious research, visually documented and transformed into a textile installation and exhibition. It had two main objectives: to create a collection using natural fabrics as wool, adding traditional motifs and inspiration from different parts of Romania, but mostly focused on Maramureș (Transylvania), and to document the entire process of processing wool (examples in Figs 7 and 8), creating an art installation that follows this journey and presented in the form of an exhibition. The resulting designs were primarily based on wool, blending traditions, and contemporary design in a personal way. I have been working closely with craftsmen that I grew up with and have had a significant contribution in shaping not only my creative path but also personal identity.

\section{SUSTAINING INDUSTRIAL CULTURAL HERITAGE SITES}

Craftsmanship plays a significant role in Romania, particularly in Transylvania, but crafts are an integral part of a wider context; they are part of a whole, a system, inside which each element is interconnected, and one could not survive and strive without the other, or at least not in harmony. In other words, we discuss the inevitable balance and interconnection between the three elements, the craftsman, the craft, and the environment in which this takes place. The entire communion follows a natural rhythm; a missing piece leads to disruption which sometimes can play a significant role. As such, cultural heritage in the area is quite complex. Therefore, heritage elements such as cultural heritage sites, as well as folklore and archaeological sites and museums, cannot be left unvoiced. They are an important part of the whole, where each piece completes the other.

The world order is uniquely perceived in a Transylvanian village through abundant and practiced cultural heritage. Surprisingly, this begins with its architecture as the human

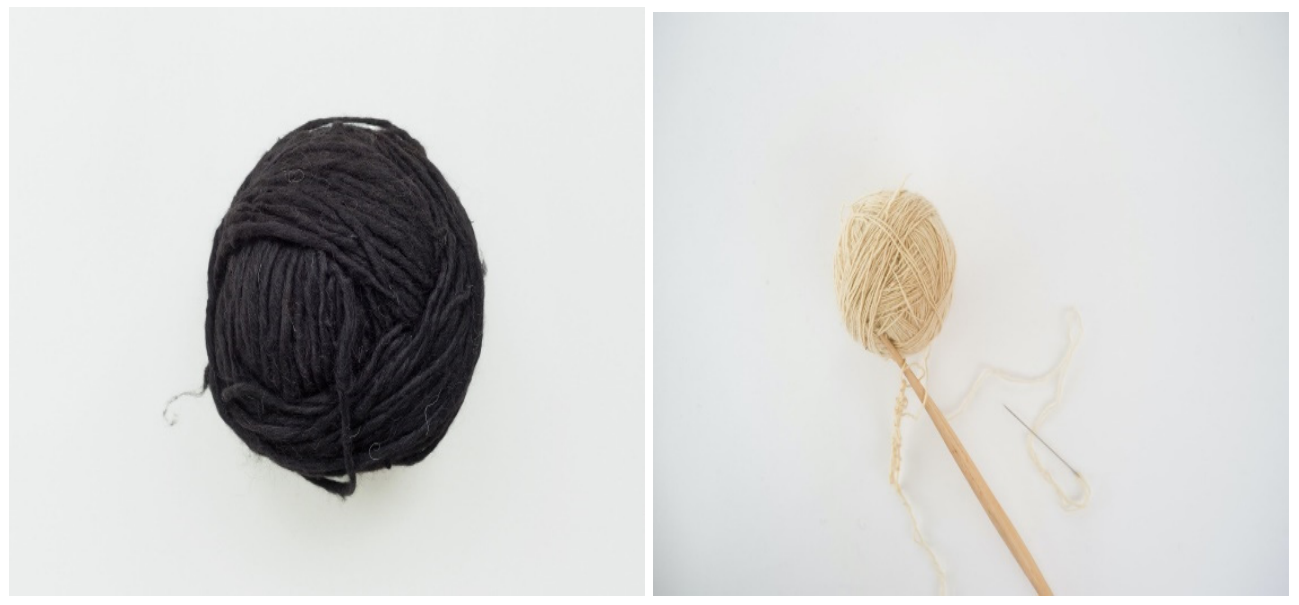

Figure 7: Wool yarns. (Source: Iulian Nan.) 

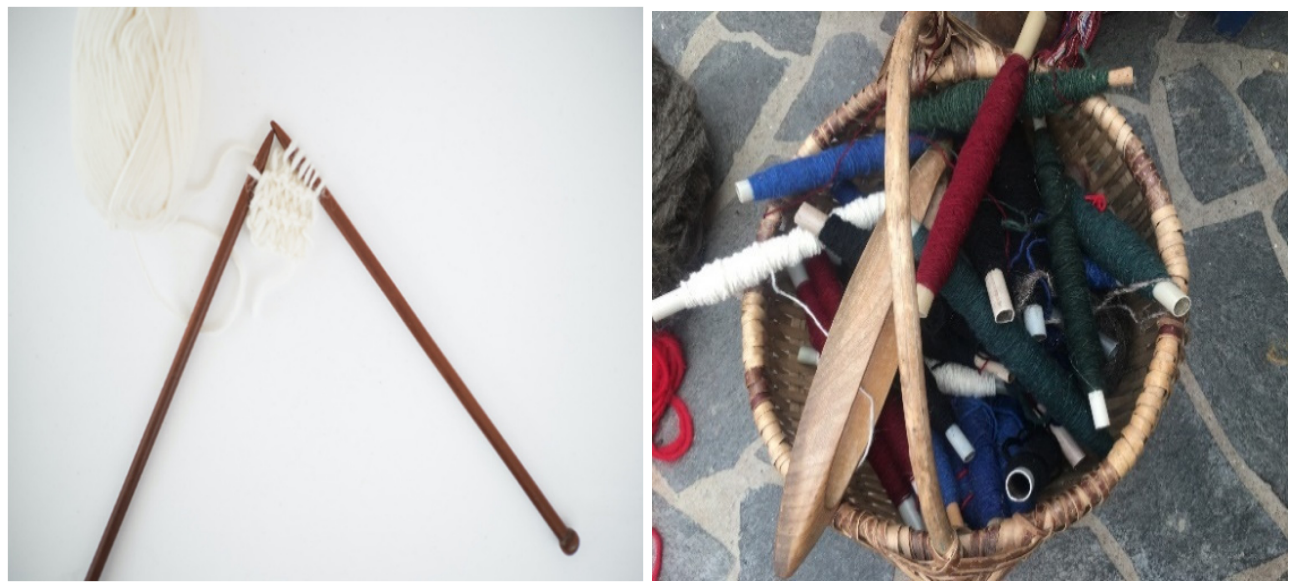

Figure 8: Wool yarns. (Source: Iulian Nan.)

establishment within its surroundings emerge in perfect harmony; each piece of the system is an extension into the other. Consequently, the local villager simultaneously played the architect role, master builder, and decorator of his own space, making a suitable habitat for living and mostly for the creation process that has an important role in their lives. This habitat stands as the starting point, as well as central core and the place of security, the shelter, the sanctuary. In general, this space has mostly perceived as having a feminine valency, as it was a woman's space, while the man was mostly out in the forests and mountains, supporting the household. The interior of traditional houses has a simple plan, with two or three rooms, evolving to more complex structures towards the late 18th century. Being planned for a pragmatic use, more than symbolic or esthetic purposes, the interior incorporates elements of contemporary comfort living amongst heritage pieces, as furniture items, textiles, soft furnishings in the form of woven carpets, rugs, embroidered towels and pottery, heirloom furniture and so on (examples of such an interior in Fig. 9). These are items that have been used with fulfilling results on a continuum bases in a household, and therefore have not been preserved as only heritage pieces but integrated into daily life for generations.

As a result of this fusion, the interior and the exterior space are not separated. A semisheltered veranda which lines the façade of the house, called "prispa" (as seen in Fig. 10), is the connecting element that has a function on its own, as well as representing a decorative touch. As part of a strong community, houses are connected amongst each other, being separated by gardens and orchards, or they are scattered on the hills.

Another architectural element that local villagers focuses on is the gate. This represents a passage between the community and the family. It is an example of craft on its own. Usually, it is crafted by local craftsmen, and it hosts an array of symbols dating from thousands of years, each gate being a unique individual work of art, guarding the sanctuary of the home within. As mentioned, the gates are made from wood, true artistic examples, wood is associated with Maramureș and Transylvania since early times. As Takács stated in her publication [7], the definition of cultural heritage is always shifting, followed by an impact on cultural cooperation practices. 


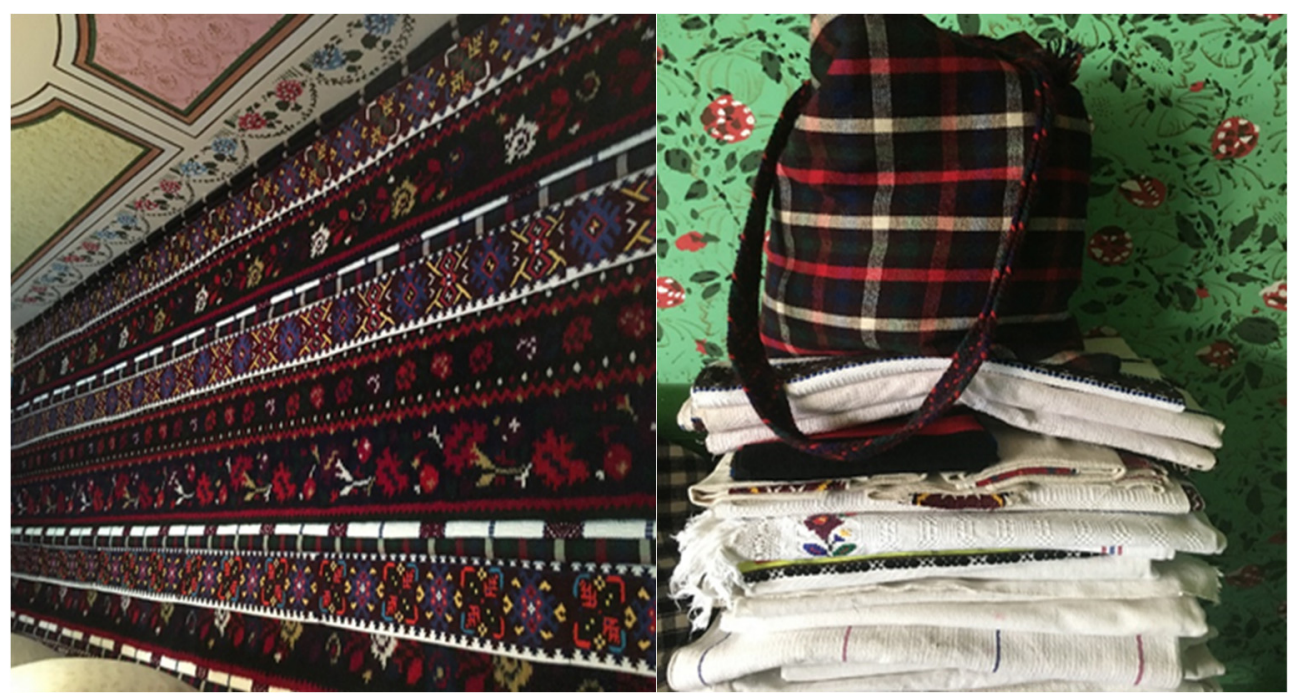

Figure 9: Living among crafts. (Source: Author.)
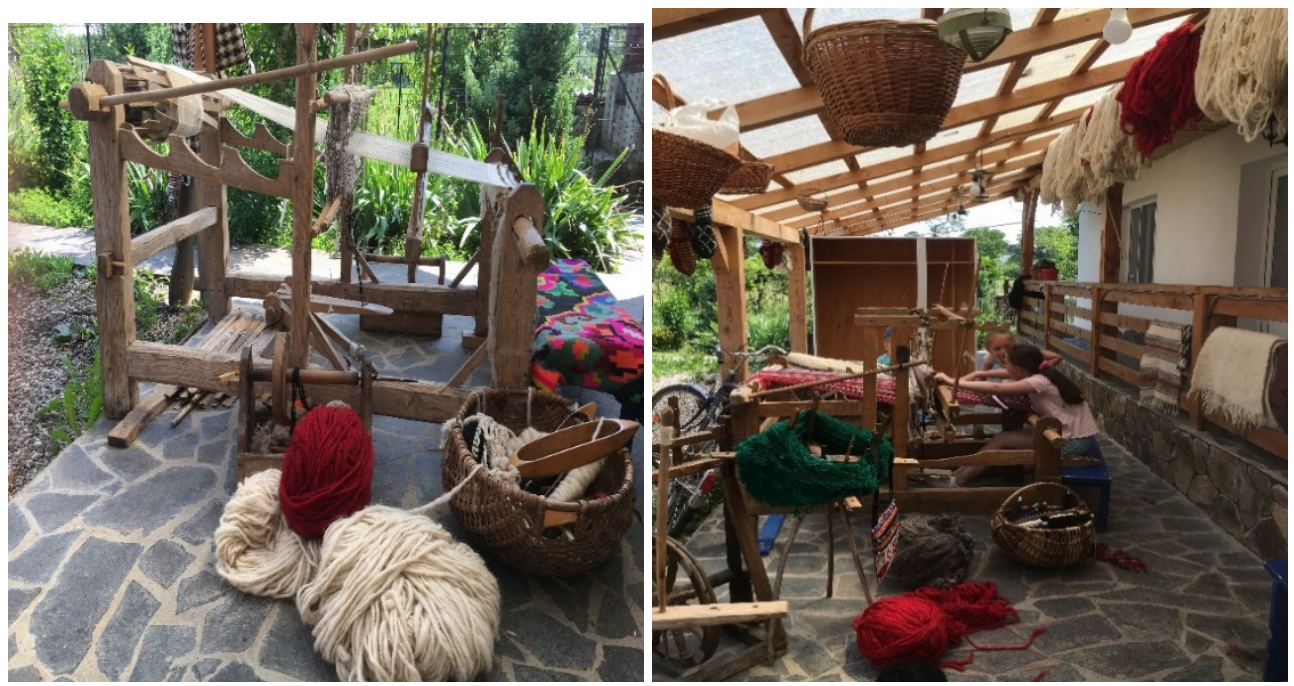

Figure 10: Verandas as workshops. (Source: Author.)

The definition used by UNESCO since the 1989 Recommendation on the Safeguarding of Traditional Culture and Folklore (http://portal.unesco.org/en) is as follows: "Folklore (or traditional and popular culture) is the totality of tradition-based creations of a cultural community, expressed by a group or individuals and recognized as reflecting the expectations of a community in so far as they reflect its cultural and social identity; its standards and values are transmitted orally, by imitation or by other means. Its forms are, among others, language, literature, music, dance, games, mythology, rituals, customs, handicrafts, architecture and other arts". 
Sustained through an interdependence between local industries and craftsmen, the latter assemble their own utter habitat in perfect harmony with nature and blend within the community at large, transmitting further the memory of the place. Traditional practices are therefore supported by "living in" museums, true examples of craftsmanship and cultural heritage, that prominent figures like Maria Zapca (weaver and textile master), Daniel Les (potter) or Virginia Linul (textiles master) conduct their entire life and activity within and avail to the world an authentic way of living and making that have been practiced by generations. These are part of the cultural fabric of Transylvania, a visual rural landscape that should be preserved by generations to come, not only in terms of ancestral practices but also for sustainable living solutions that have been proven to be effective over time. Showing the results to the world, means sustaining a small community in the 21 st century.

\section{CONCLUSIONS}

This unique land is an authentic ethnographic paradise, traditional costumes that offers true examples of craftsmanship, powerful symbolic motifs, cultural heritage sites and unique habitat solutions, a bonded community powered by spirituality and wisdom, living by harmonious guidelines.

The interdependence of nature and people has created a remarkable atmosphere, an identity of mood that permeates local heritage diversity. Transylvanians attach significance to buildings and to places around the region. The reinforced heritage has played a distinctive role in helping to define the values of society. People around the region take great pride in their unique practices and customs. Do not hesitate to show it to the world, reflecting the rich heritage continued by generations, the quality of life, and the uniqueness of society. The architecture, creative direction, custom, and practices are an integral part of their cultural identity, in which they conduct their lives.

Above all, Transylvania is a land that stands as a unique historical and cultural experience, reinforced by its people who have continuously lived and worked here, have been part of the landscape, and built their own perfect habitat in harmony with nature and community. Nothing is left aside, and everything is integrated, everything finds its place here and has a contribution in enhancing the valences of this amazing place. It is a lifestyle that takes it beyond space and time, and the journey of wool is a means to authentic emotional storytelling.

Consequently, the aim is to continue to preserve local crafts through the production of diverse and actual cultural projects, as well as documenting and implementing the results within relevant and meaningful contemporary practices. To encourage this authentic way of living, immerse in it to make it viable with the contemporary approaches, the following recommendations are inferred:

- The continuous adoption of authentic and traditional crafts as a means for modern inspiration, sustainable local economies, and promotion of living cultural heritage sites.

- Incorporating ancestral crafts into contemporary designs to ensure continuity of both and local aesthetics.

- Allow local craftsmen to utilize existing cultural heritage sites and traditional locations to maintain authenticity or practice and place.

- Discuss similar case studies within international frameworks to exchange know-how and best practices. 


\section{REFERENCES}

[1] Szabó, T., Povestea Lânii, Editura Tradiţii Clujene: Cluj-Napoca, 2016.

[2] Zaharia, F., Textile tradiţionale din Transilvania: tehnologie şi estetică, Suceava, Accent Print, 2008.

[3] Bănăţeanu, pp. 133-135, 1985.

[4] Evseev, I., Dicționar de simboluri și arhetipuri culturale, editura "Amarcord", Timişoara, 1994.

[5] Iuga, A., National Museum of the Romanian Peasant, Bucharest, Romania, 2016.

[6] Clițan, A.C. et al., A wool journey: from fashion design to art installation, Cultural project co-financed by the Administration of the National Cultural Fund, Atelier 13, Dichis și Dungă, 2019.

[7] Takács, I.C., Multicultural and intercultural common heritage in Transylvania, International Journal of Education. Culture and Society, 2(5), pp. 147-157, 2017. DOI: $10.11648 /$ j.ijecs. 20 170205.12.

[8] Hallett, C. \& Johnston, A., Fabric for Fashion, The Complete Guide: Natural and Man-made Fibres, Laurence King Publishing: London, 2014.

[9] The Woolmark Company, The Wool Lab A/W 16/17. Material Innovation \& Technology, 2017. https://www.wgsn.com/content/board_viewer/\#/59262/page/1.

[10] Wang, J., Once wool, Forever wool: Exploring wool's technique improvements, sustainability and future trends. Course name: Fibre to Fabric Product Knowledge, RMIT University, 2017.

[11] Bănățeanu, T., Portul Popular din Regiunea Maramureș, Sfatul Popular al Regiunii Maramureș, Casa Creației Popolare, 1970.

[12] Dogaru, O., Ornamentul și croiul costumului popular din județul Maramureș, Baia Mare, 1984.

[13] Paşcan, C., Lîna, materie primă milenară, Bucureşti, 1982.

[14] Deculescu C. (ing.), Indrumător pentru finisarea ţesăturilor de lînă, Editura Tehnică Bucureşti, 1963.

[15] Ifrim, S., Chimia lânii, ed. a 2-a, Performantica: Iași, 2006.

[16] Lazar, R., Meşteşuguri tradiţionale din Ţara Maramureşului, fotografii Radu Lazar, text Teofil Ivanciuc, corectură şi rezumat în limba engleză Adela Ulici, Baia Mare, Editura Proema, 2016.

[17] Şerba, M., 1945, Cămeșa de sărbători - Maria Șerba, Ileana Șandor, Măriuca Verdeș; prefața Delia Suiogan, Sighetu Marmaţiei, Editura Valea Verde, 2016.

[18] Russu, Ioan I., Elemente autohtone în terminologia ocupaţiilor [extras], Cluj [s.n.], 1963.

[19] Maier, R.O., Meşteşuguri ţărăneşti tradiţionale în spaţiul românesc, Editura Etnologică: Bucureşti, 2009.

[20] Nițulescu, V.Ș., Patrimoine culturel immatériel de Roumanie, répertoire $I=$ Patrimoniul cultural imaterial din România: repertoriu I, Traducere în limba franceză Cristiana Papahagi, CIMEC - Institutul de Memorie Culturală: Bucureşti, 2009.

[21] Bassa, B., Raica, I., Valea, M. \& Lungu, I., Meşteşuguri şi meşteşugari din sudvestul Transilvaniei, Editura Ştiinţifică: București, 1970.

[22] Stoica, G., Meşteşuguri artistice tradiţionale, Georgeta Stoica, Olga Horşia; o prefaţă de dr. Paul Petrescu, Editura Enciclopedică: București, 2001.

[23] Pavelescu, E., Meşteşug şi negoţ la românii din sudul Transilvaniei (sec. XVII-XIX), Editura Academiei Republicii Socialiste România: București, 1970. 
[24] Meşteri = Artisans = Maistri, Maramureş, România, Transcarpatia- Ucraina- Baia Mare, Fundaţia social - culturală pentru democrație, identitate, unitate, generozitate, acţiune, 2008.

[25] Răchișan, D.A., Tradiţii, identitate naţională, dialog intercultural, diversitate, conferința internaţională, ediția a 3-a, Baia Mare, 27-28 Octombrie 2017, Traditions, National Identity, Intercultural Dialogue, Diversity, International Conference, the third edition, Baia Mare, 27-28 Oct. 2017, Editura Mega Argonaut: Cluj-Napoca, 2017.

[26] Bencze, N., Bora, A., Ciocan, M. \& Dorolți, A., Tradiţii şi obiceiuri în Maramureş, publicaţie coordonată de conf. univ. dr. Delia Suiogan, Baia Mare [s.n.], 2010.

[27] Datcu, I., Tradiţii din Maramureş, Grai şi suflet - Cultura naţională: Bucureşti, 2009.

[28] Fulga, L. \& Chiru, G., Discursul ritual şi costumul tradiţional din sud-estul Transilvaniei, Braşov [s.n.], 2018.

[29] Roșu, G., Magiru, M. \& Dăncuş, M., Costumul tradițional în România, The traditional costume in Romania, cuvânt înainte = forward: Dr. Ioan Opriș; versiunea engleză = English version: Ana Maria Palcu, Editura Alcor Edimpex: București, 2011. 